\title{
BRITISH FICTION AND \\ Cross-Cultural Encounters
}





\section{BRITISH FICTION AND \\ Cross-Cultural Encounters \\ ETHNOGRAPHIC MODERNISM FROM WELlS TO WOOLF}

Carey J. Snyder 


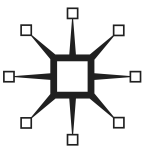

BRITISH FICTION AND CROSS-CULTURAL ENCOUNTERS

Copyright (C) Carey J. Snyder, 2008.

Softcover reprint of the hardcover lst edition 2008 978-0-230-60291-5

All rights reserved. No part of this book may be used or reproduced in any manner whatsoever without written permission except in the case of brief quotations embodied in critical articles or reviews.

First published in 2008 by

PALGRAVE MACMILLAN ${ }^{\mathrm{TM}}$

175 Fifth Avenue, New York, N.Y. 10010 and

Houndmills, Basingstoke, Hampshire, England RG21 6XS.

Companies and representatives throughout the world.

PALGRAVE MACMILLAN is the global academic imprint of the Palgrave Macmillan division of St. Martin's Press, LLC and of Palgrave Macmillan Ltd. Macmillan ${ }^{\circledR}$ is a registered trademark in the United States, United Kingdom and other countries. Palgrave is a registered trademark in the European Union and other countries.

ISBN 978-1-349-60285-8ＩSBN 978-1-137-03947-7 (eBook) DOI $10.1007 / 978-1-137-03947-7$

Library of Congress Cataloging-in-Publication Data is available from the Library of Congress.

A catalogue record of the book is available from the British Library.

Design by Scribe Inc.

First edition: March 2008

10987654321

Transferred to Digital Printing in 2013 
For Mark and Zachary 



\section{CONTENTS}

Acknowledgments viii

Introduction Ethnographic Observers Observed $\quad 1$

1 Explorer Ethnography and Rider Haggard's African Romance, She

2 Bewilderment as Style and Methodology in the Writings of Mary Kingsley, H. G. Wells, and Joseph Conrad

3 Self-nativizing in Virginia Woolf's The Voyage Out 97

4 E. M. Forster's A Passage to India and the Limitations of Ethnographic Rapport and Understanding

5 "When the Indian Was in Vogue":

D. H. Lawrence, Aldous Huxley, and Ethnological

Tourism in the Southwest

Conclusion

Notes

Works Cited

Index 


\title{
ACKNOWLEDGMENTS
}

\begin{abstract}
$\mathrm{T}$ his book began as a conversation with the late Michael Sprinker over a pint of ale at the Printer's Devil in Port Jefferson, New York. Energized by having read James Clifford's Predicament of Culture, I proposed that ethnographic ideas and relationships were somehow at the core of literary modernism. Michael encouraged me to pursue the idea (perhaps rashly, given its scope); it eventually yielded a dissertation and now, in a much different and expanded form, the book before you. Given the project's long evolution, Michael is the first of a long list of individuals whose contributions I am pleased to acknowledge, for without their support, inspiration, and feedback, this book could not have been written.
\end{abstract}

At the dissertation stage and beyond, I benefited greatly from the professional mentorship and constructive criticism of S.U.N.Y. Stony Brook faculty members Helen Cooper, Eric Haralson, and Adrienne Munich, as well as from the feedback and support of a wonderful cohort of graduate students, including Melissa Bradshaw, Julie Burton-Swift, Jenni Frangos, Matthew Herman, Heidi Johnsen, Chris Nagle, Sarah Stow, Patricia Vassos, and Jessica Yood. Renato Rosaldo's input as an outside reader was also indispensable at this early stage. To the roll call of Stony Brook faculty and alumni who have contributed to this project, I must add Celia Marshik, the modernist who, to my misfortune, was hired the year after I graduated, whom I have nevertheless had the pleasure of coming to know on the conference circuit, and whose feedback and support I have valued.

At Ohio University, I am fortunate to be a member of an exceptionally collegial department, which has fostered my professional and personal development in many ways. English Department chairs Ken Daley and Joe McLaughlin both served as advocates, generously affording me time for researching and writing this book. Joe also attentively read and commented on large portions of the manuscript. Andrew Escobedo's faculty colloquium series created an 
important forum for sharing work and ideas; additionally, he has been a helpful reader of my work. Other colleagues I'd like to thank include Josie Bloomfield, Mark Halliday, George Hartley, Mara Holt, Paul Jones, Beth Quitslund, Nicole Reynolds, Lisa Stein, Jeremy Webster, and Johnnie Wilcox. I also appreciate David Bullock's able assistance with citations. My thanks, too, to the anthropologist Steve Rubenstein, with whom I have enjoyed many stimulating debates and conversations and whose input, on Chapters 4 and 5 especially, was important. I am grateful to the late Dean McWilliams for offering indispensable editorial input on the completed manuscript. Colleagues at other universities, especially Eric Aronoff and John Marx, have made significant contributions to this project as well. Thanks also to Molly Maloney, for her unstinting support.

In a category of their own are Marc Manganaro, Melba CuddyKeane, and James Buzard whose encouragement, shrewd attention to the manuscript, and repeated, generous support helped cultivate and bring this project to fruition. Melba Cuddy-Keane served as an inspiring role model and mentor; her intervention on an early draft of Chapter 3 proved a turning point in reshaping the project as a whole. Marc Manganaro's stimulating seminars on modernism and anthropology at the Modernist Studies Association's annual conferences (2002-4) provided a much-valued forum for sharing ideas; his expert input, enthusiasm, and example left an important mark on this book. James Buzard's astute scholarship, as well as his valuable feedback and support, has also significantly influenced my work.

Research for Chapter 5 was made possible by a grant from the Ohio University Research Council. Tomas Jaehn, the archivist at the Fray Angelico Chavez Research Center in Santa Fe, New Mexico, ably aided me in locating materials used in that chapter. It was published in article form in Modern Fiction Studies 53.4 (Fall 2007); my thanks for permission to reprint it here. Thanks also to Woolf Studies Annual for allowing me to reprint Chapter 3, which appeared as "Woolf's Ethnographic Modernism: Self-Nativizing in The Voyage Out and Beyond" in Woolf Studies Annual 10 (2004): 81-108.

Throughout the writing of this book, I have been sustained and encouraged by my family. Such debts of gratitude are impossible to properly tally. However, I would like to especially acknowledge my mother, who inspired not only a love of reading but also an early interest in anthropology, and my grandmother, who has been a lifelong inspiration. For their unwavering confidence in me, I would 
also like to acknowledge my father and his wife. For their encouragement and good humor, I am indebted to my sister and brother. And for living with this project for eight years, doing a better job than $\mathrm{I}$ in translating its ideas into common parlance, and taking up the household slack to enable me to finish it-as well as for abundant love, encouragement, and patience-I must thank my husband, Mark. Lastly, I must thank the delightful Zach, though he only arrived when I was undertaking final revisions, for he humbled and inspired me, and put all other labor into perspective. 